\title{
The relationship between customer care and business volume in KCB-Rwanda
}

\section{Laura Baijahe Uwase ${ }^{1}$,Dr. James Kant Kamuhand ${ }^{2}$ and Mr. Onsoti Sammy Nyabera ${ }^{3}$}

\author{
${ }^{1}$ School of Business and economic, Mount Kenya University, \\ Kigali, Rwanda \\ ${ }^{2}$ School of Health sciences, Mount Kenya University, \\ Kigali, Rwanda \\ ${ }^{3}$ School of Business and economic, Mount Kenya University, \\ Kigali, Rwanda
}

\begin{abstract}
The research study was conducted in KCB bank Rwanda Ltd head office in Nyarugenge district under the topic "Customer care and business volume in a banking industry" The study found out the relationship between customer care and business volume particularly in the banking industry. This experiment was chosen to find out how and why these two variables were related and how banks and other related businesses can improve on sales volume and build market share. To achieve this, the research was guided by three objectives which are: To identify customer care strategies, challenge in the customer care services and to find out the relationship between customer care and business volume. The research serves mix method approach including descriptive survey design with 192 respondents composed of $95 \mathrm{KCBR}$ beneficiaries and 97 KCBR Staff. The results were harmonized by focus groups' discussions with beneficiaries. Purposive sampling and simple random sampling have been used to choose staff and beneficiaries who participated in this research to create an equivalent representative in a population. The questionnaire was the main tool to collect information, and interview was used and the final accomplished work, serves as document of academic purpose and its findings helped other researchers and the Rwandan community in general and KCBR to improve its program. The study revealed a variation of Increase Net Promoter Score (after a market survey) from 2017 to 2020. Indicators show that the NPS was $30 \%$ in consecutive three years $(2017,2018$, and 2019) but increased to $42 \%$ in 2020 due to the use of new alternative channels that were used by clients during
\end{abstract}

Covid 19 Lockdown. The study asserts that handling customer complaints is more likely to affect positively business volume with a $\mathrm{p}$ value of 0.010 , $\mathrm{t}=2.69$, the correlation between customer care policy at $\mathrm{KCB}$ Banks and business volume is insignificant with a $\mathrm{p}$ value of $0.556, \mathrm{t}=0.594$. Since the study proved that there is a relationship between customer care and business volume. In additional, the researcher recommended that KCB Bank should invest more on what can improve customer care, meet the customer needs and satisfaction and should invest on the use of alternative channels especially technology including internet banking, mobile banking, ATM use and other services that do not require to enter the banking hall.

Key words: Business Volume in Banking Industry, Customer Care, Customer Value and Customer orientation

\section{Introduction}

Most industries as well as businesses persistently attempt to maximize customer value. Nonetheless, this has globally become the focal point of marketing for each organization and company within Africa. In order for any company to attain this goal, there is always a requirement to get customer approval through presenting extra ordinary services to clients. Indeed service is the ability to identify the needs beyond their expectation within the shortest possible time (Armstrong, 2010). In this light, the focal point of marketplace is to attend to the customers' requirements, needs favorite and thoughts.

Arguably, marketing concepts posit that the right venues to start the search for new product ideas are 
the customers' needs and wants (Baruah, 2013). It is evident that for any organization to be successful, the integration of facts about customer's desires, wants as well as preference must be put in place. The competitive edge is protected throughout smart classification and approval of customers' needs improved and closer than competitors.

In East African countries, Rwanda in particular, ensures quality customer care in service delivery among private and public institutions including Banking Industries is at the forefront. Customer care is the mother of quality service delivery (Company, 2011). As customer care referred to service that one may give to another essentially intangible and did not emanate from ownership of anything but brings about customer value and satisfaction (D'yakonov, 2013)

As indicated by (Goncharenko, 2012), customer care is a service that looks for obtaining new clients, maintain the existing services that exceed customer expectation and make customer reliability. Customer care services in a company comprises but not limited to "attractiveness, consistent services, security, front desk services, parking space, and speed in service provision, after sales services, customer orientation and sensitivity to their expectations, integrity and good habits towards clients. Client care services are alerted on inventing the customer relaxed, generate excellent dealings in the brainpower of the clients, and building them believe to be improved, happy than they were previous to the business, and motivate consumer preservation. In this study, business volume is defined as a large commercial organization.

In Rwanda, the economy of the country hinges on the financial institutions' effectiveness. Therefore, the banking industry is more encouraged to promote customer care as a competitive advantage. The banking sector is a dynamic and pertinent element to persons, companies, small and medium businesses, national and global, economic, social and financial welfare. This sector is about financial interactions with clients of all size to afford financial products and services that stimulate economic development and act as a catalyst to national and global economics (Wandaogou\&Jalulah, 2011).

Wandaogou and Jalulah (2011) adds that a business' prosperity is concluded as far as its thriving which is the inclination of the firm to get. This arrival is an extent of deals, assignments of assets contributed, or allotments of assets used. Business volume is altogether misrepresented by client care rules notwithstanding item quality, item picture, information about the item, after-deals administrations.

\section{ISSN 2455-6378}

Therefore, any business with a great goods and services but no customer care and what to sell it has been prolonged into waste leading to loss in terms of sales and business volume. The firm's capital has little value when the number of customers is very low owing to the lack of customer care (Novikov, 2011). The main objective a company is to draw customers and be capable to preserve them. It is significant to write down so as present is client approval, afterward the consumers are further expected on the way to stay as loyal customers.

For example, Lee (2000) noted, "All customers are entitled to free delivery of their purchase irrespective of the quantity." From this concept, his business increased its customer base and sales volume. Every day customers were floating to the firm's premises. It is said that the project was designed as a tool to increase sales volume. Any business is supposed to first centered on the requirements as well as after that on the earnings provided that single to one marketplace with worth sequence of products service which tops in improved trade volume during confine customer share, constancy, as well as lifetime significance. Therefore, the aptitude of a business to compact with client's solitary at a time has to ensue to be useful as a resource of development (Potluri\&Mangnale, 2011).

Although the management of Rwanda has put more effort to encourage banking industries to realize good customer practices, some banks still confronting a challenge of customer care policy. It is revealed in instances where customer objections are not wellhandled for the reason of frustration, delays on the counter, delays in service delivery, inadequate parking space for customers (Company report, 2011). This situation has affected the bank's business growth. Therefore, unless organizations rethink their customer strategies, they kept on acquiring a loss within the structure of lost customers hence therefore influencing their business volume or customer base. KCB Bank Rwanda Ltd is a subsidiary of the KCB Bank group. The bank fully started its operations in Rwanda in 2008 focusing mainly on putting the customer first. This worked as a wakeup call for other banks in Rwanda and even other companies in general. Consequently, many companies in Rwanda came to understand so as to their continuing competitiveness is trained by customer preservation. In order to realize this, there is a requirement to transform the way the customer is professed by applying bilaterally communication with him, by winning the customer's belief, by making treatment with him the same as a colleague that can supply to value conception.

It has been argued that the size of business increases as the profitability also increases. However other scholars such as (Potluri and Mangnale, 2011) strongly argue that the correlation between business 
volume and bank performance is complex and is still a myth to other researchers. This means there is still a gap of the correlation between the two variables. Despite the issues stated above, Banks in Rwanda have put much effort into promoting customer care to increase customer satisfaction which in turn is believed to increase the business volume. Little is known about what could be causing this complexity linking customer care and business volume in banking industry. It is in this regard that this study intended to establish the correlation among consumers care as well as business size in the business attractive a "case of KCB Rwanda Bank Limited".

\section{Review of Literature}

Theoretical literature provides a theoretical review of customer care and business volume in banking sector. In this regards, it described in deep key concepts related to the research topic such as customer cares, customer satisfaction, definition of customer care service, business volume, strategies of customer care, challenges in customer care, and relationship between customer care and sales volume.

\subsection{Customer Care Strategies}

Customer Care Strategies are designed to establish stability within output at the same time as make certain that individual can be receptive to person desires moreover at the same moment wanted by the customer (Haenisch, 2012). Several strategies for customer care were described by Mahapatra, (2018) which are Seek Customer Feedback, strengthen Your Customer Service Team, use CRM Platforms and leverage Multi-Channel Servicing.

According to Ishchenko (2014), it is significant to write down that the customer care strategies affect toward every services. Though, customer care strategies are also a structure that allows services person to make further promise to their clients concerning the way the services are delivered.

Organizations are real knowledgeable on the way to control their clients' potential through typical situate for them through a set of conference on customer care guidelines where clients have to set expected norms (Northouse, 2010). Businesses should consider that they are not big business through not succeeded goods except by the feelings of people sourced through failed goods.

According to Novatorov and Novitskaya (2012), companies must equip their employees with skills and knowledge by developing a portfolio modular of customer care guidance which is compulsory to meet up the customer care strategies. Salimova (2013) noted that the training progresses by including custom made program as obligatory related on comments given by staff members and clients. The public services may usually emanate from contact with clients that are in critical conditions and usually at complying with rules and regulations they have a responsibility to apply. Workers are skilled enough to copy with their needs including sensitive problems to the highest level of care is provided to their clients (Toolkit, 2013). Significantly, it is how organizations solved the pertinent issue and customer care knowledge that is adopted in service rescue and rendering an adjustment to ensure that the same error did not occur again (Toolkit, 2013).

As indicated by Jeston and Nelis (2013), the essential marketing assets are the customers. Their statement of mouth proposal is far further fruitful than all other promoting exercises set together. Agreed their ambassador role, organizations should make marketing the most important department moreover if required; create a customer care role to exceptionally serve its assets (customers) far more productively.

According to Abidoo (2011), customer knowledge management gives a systematic and well managed model to assess and coordinate client comments to know that they are utilized to increase development in providing customer care with high quality. For the purpose of delivering what client judge as excellent, the study felt what they intend and if it meets those expectations. It is pertinent to set up workers ideas towards customer care and access to instruments that are necessary to afford better customer care services (Agbor, 2011).

The product price must be comprised of cost of getting services and cost of retention like service cost owing to its ability to make sale price more favorable can force the brand to recoup the loss margin via various operations (Amah \&Ahiauzu, 2013). The study know that client did not merit the best service owing to the fact that the price for sales is not high. Goods' price may bear enough margin to respond customer needs (Anandpadmanabha, 2011).

\subsection{Relationship between Business volume and Customer care}

According to Isaev (2011) argues that the empirical data on the above stems starting 2009 from that it may be felt that is favorable to discover evidence for the anticipation that there is a positive correlation customer satisfaction and organizational success measures. Various elements may affect the time- lag between a change in client satisfaction and an expected effect on sales margin or other outcomes measures.

Several businesses with huge merchandises except no buyer base rapidly observed it available to resulting immense loss in terms of transaction amount sold. The company's property comprises small value with no existence of consumers. Therefore, to serve the customers or consumers is the 
main responsibility to them for getting benefits (Isaev, 2011). To attract and able to keep the customers is the key company's duty.

According to Potluri and Mangnale (2011), improved net profit related to customer retention efforts appears of several elements that appear once a correlation has been found with a customer that contain, the price acquisition appears at the beginning of cooperation. According to Salimova (2013) argued that the relationship marketer's objective engages supplying further adapted "service and providing service quality" to top prospect by every stage. However, the report between clients approval with business volume in terms of trade performance (profits) is not always very clear (Simon \&Nimako, 2010).

Customer care service is key to retaining customers. The customer care service significance toward business is highlighted through one of the writers Uddin and Akhter (2012) who emphasized that good customer service comes in all shapes and sizes no matter what size of the business. There is a tendency to think that customer care service mainly applies to large or big business organizations. But the quality of service a company delivers depends on the commitment to excellence and not size. So, all organizations and companies should endeavor to provide good customer service because it's key to customer service and satisfaction and business growth (Wandaogou\&Jalulah, 2011).

A most important instrument for market dissemination is customer service (Agbor, 2011). He noted that businesses usually looks forward to winning and increase their turn over every time by applying basic strategies that may stimulate and meet customers' needs such as providing after-sale service (Abidoo,2011) concurs with the choice to retain customer care happiness which is, whatever satisfies customers is the major profit that generate royal customers.

\section{Materials and Methods}

A research design denotes a technique that gives a deep description of features of the respondents that are investigated (Kombo, 2011). In this research about "assessment took a contextual investigation on KCB Bank Rwanda Constrained. The idea of the contextual analysis was portrayed by Blaxter, et al., (2010) characterize a contextual investigation as a strategic qualitative research methodology. A target population consists of groups of persons considered from the entire population that share similar characteristics and is identified as the intended audience for the research (Jackson, 2016). As the whole of population and/or objects with which a research is concerned Population may be viewed as a body of people or any other collection of items under consideration for the research purpose. In this study, only employees of KCB Bank Rwanda head office form the study people throughout the sample which were described. A total of 192 respondents have been targeted including 97 employees of head office (staff) and a sample of 95 clients was the target population calculated from clients of KCB of head office and the staff which were 6255 and 138 of clients and staff respectively.

The researcher involved both categories including staff and beneficiaries of KCB Rwanda Bank Limited in the study because they possess the necessary study information. It is very complex to question and assess the information from the entire population at the study process. That is why there is an expectation to select the sample of the target population.

The sample size from the staff category has been determined using proportional piling at $70 \%$ of the target population. Drost (2011) noted that proportional piling is a quantification technique and an interactive method used to generate a discussion, the disagreement, and eventually consensus. It used to obtain qualitative information about comparable items.

The study employed Alain Bouchard formula that illustrates that a population below $1,000,000$ persons, the sample size may be 96 with an estimated error of $10 \%$ and $90 \%$ of precision (Muhaturukundo, Shukla \&Mbabazi, 2016).

\section{$\mathrm{N}=$ Population Size}

No: Sample Size, when the population size goes towards infinite is 96

\section{Nc: Corrected Sample Size}

$$
N c=\frac{N \times N o}{N+N o}=\frac{6255 X 96}{6255+96}=94.5 \cong 95,
$$

Thus, the sample size is 95 individuals for the clients.

The sample size for $\mathrm{KCB}$ staff, is calculated as follow:

$$
N c=\frac{N x 70}{100}=\frac{138 \times 70}{100} \cong 97 \text { individuas }
$$

In this illustration, one hundred and ninety two (192) respondents have been sampled (including 6255 clients and 138 staff) were selected using simple random sampling techniques. To gather qualitative and quantitative information, formulated questionnaire was distributed to one hundred and ninety two (192) randomly selected from KCB clients. The sampling interval has been applied and calculated as:

Staff $=138: 97=1.4$ and Clients $=6255: 95=66$ 
Table 3. 1Distribution of Sample Size

Target Population $\quad$ Sample Size

\begin{tabular}{lcc}
\hline Staff & 138 & 97 \\
Beneficiaries (clients) & 6255 & 95 \\
Total & $\mathbf{6 3 9 3}$ & $\mathbf{1 9 2}$ \\
\hline
\end{tabular}

Source: KCB (2020). Annual Report and Financial Statement

\subsubsection{Sampling Technique}

Sampling technique consists of way from which the author adopts for collecting information from individuals, locations or other elements. It is the choice of sampled respondents known as representation system drawn from the whole population (Drost, 2011). As indicated by (Kothari, 2010) simple random is adequate in establishing equal representative groups that are pertinent the same on all relevant variables by researchers. A purposive sampling as described by Alivi (2016) is a non -random sampling in which the selection of the sample is relied on personal proficiency on the population. Simple random sampling technique for this research was in use to choose employees, also purposive technique to get strata as well as stratified simple random sampling to clarify staff and administrators.

\section{Results and Discussion}

\subsubsection{Gender of Respondents}

Gender profile is pertinent and form a baseline information in assessing the role of customer satisfaction on business volume. Information are presented in Table 4.1

\section{Table 4.1 Gender of Respondents}

\begin{tabular}{lcc}
\hline Gender of Respondents & Frequency & Percentage \\
\hline Male & 105 & 54.7 \\
Female & 87 & 45.3 \\
Total & $\mathbf{1 9 2}$ & $\mathbf{1 0 0 . 0}$
\end{tabular}

\begin{abstract}
Source: Primary Data, 2021
Results presented in Table 4.1 indicated that at male are $54.7 \%$ and female are $45.3 \%$ of respondents. This profile is pertinent to the researcher in the course of analyzing the acceptance of customer satisfaction strategies and its effects or business volume. This age is favorable in the context of Uddin and Akhter, 2012) who perceived that gender balance is more like to increase business volume in order to fulfill clients construct monotonous buys just as execute high rate towards the organization's merchandise or services.
\end{abstract}

\subsubsection{Age Brackets of Respondents}

Age group of respondents very important and form a baseline information in assessing role of customer satisfaction on business volume. Information are presented in Table 4.2

Results demonstrated that $40.1 \%$ of respondents are between 31-40 years old. This means that KCB workers are relatively young and this may affect how customer care strategies are used. This research concur with the observation of Wandaogou and Jalulah (2011) remarks to satisfy clients preserve a positive attitude towards service providing company. Therefore, group ages are very important in assessing the effects of customer care to business age. Clients are satisfied, they had confidence in firm and are willing to collaborate with a firm's employees. 
Table 4.2 Age Brackets of Respondents

\begin{tabular}{lll}
\hline Age Brackets of Respondents & Frequency & Percentage \\
\hline $16-24$ & 11 & 5.7 \\
$25-30$ & 46 & 24.0 \\
$31-40$ & 77 & 40.1 \\
$36-45$ & 58 & 30.2 \\
Total & $\mathbf{1 9 2}$ & $\mathbf{1 0 0 . 0}$ \\
\hline
\end{tabular}

Source: Primary Data, 2021

Table 4.3 Marital Status of Respondents

\begin{tabular}{lll}
\hline Marital Status of Respondents & Frequency & Percentage \\
\hline Single & 33 & 17.2 \\
Married & 97 & 50.5 \\
Divorced & 58 & 30.2 \\
Widowed & 4 & 2.1 \\
Total & $\mathbf{1 9 2}$ & $\mathbf{1 0 0 . 0}$ \\
\hline
\end{tabular}

\section{Source: Primary Data, 2021}

The study demonstrated that $17.2 \%$ of respondents are single, $50.5 \%$ are married while $30.2 \%$ of sampled population are divorced and $2.1 \%$ are widowed. These show that most of respondents had responsibility to assume in their families. This study is relevant with findings of Ishchenko (2014) who recognizes with the intention of appreciating customer care by clients when clients are married or divorced owing the responsibilities they have to assume. In most organizations, customer satisfaction means profitability.

\subsubsection{Education of Respondents}

Education of respondents was very pertinent in examining the role of customer care on business volume in banking institutions.

Table 4. 4 Education of Respondents

\begin{tabular}{lll}
\hline Education of Respondents & Frequency & Percentage \\
\hline Primary & 6 & 3.1 \\
Certificate & 29 & 15.2 \\
Degree & 117 & 60.9 \\
Diploma & 40 & 20.8 \\
Total & $\mathbf{1 9 2}$ & $\mathbf{1 0 0 . 0}$ \\
\hline
\end{tabular}

confirmed the role of education level in increasing business volume. The study assumes that if staff

\section{Source: Primary, 2021}

Information demonstrated that $60.7 \%$ of respondents hold degree (Bachelor's degree), while 20.9\% of respondents had diploma, $15.2 \%$ of respondents had secondary school certificate while $3.1 \%$ did not attend secondary education. Ishchenko (2014) members had a university level, they tend to provide high quality of services and increase business volume. In most organizations, customer satisfaction means profitability.

4.1.4 Working Experience at KCB

It was pertinent to know working experience of respondents in Table 4.5 
Table 4. 5 Working Experience.

\begin{tabular}{lll}
\hline Working Experiences & Frequency & Percentage \\
\hline 6 Months- 2 Years & 33 & 17.2 \\
3.5 Years & 97 & 50.5 \\
6-8 Years & 58 & 30.2 \\
Above 8 Years & 4 & 2.1 \\
Total & $\mathbf{1 9 2}$ & $\mathbf{1 0 0 . 0}$ \\
\hline
\end{tabular}

Source: Primary Data, 2021

The study indicated that $30.2 \%$ had experience between 6 months to 2 years. While $50.5 \%$ of respondents had been working or benefiting from KCB for the last five years. These show that most of workers and beneficiaries are retained to $\mathrm{KCB}$. This study concur with the fact that customers that continue to be with you have a tendency to be contented through the relationship as well as less probable to control the competition, building it not easy for participant for competing to go into the market or increase market share (Amah \&Ahiauzu, 2013).

4.1.5. In which department do you work?

It was pertinent to know respective department or categories of respondents in Table 4.6

Table 4. 6 In which department do you work?

\begin{tabular}{lcl}
\hline Working Experiences & Frequency & Percentage \\
\hline Account & 4 & 2.1 \\
Management & 8 & 4.2 \\
Sales & 19 & 9.9 \\
Internal Audit & 4 & 2.1 \\
Customer Care Service Department & 62 & 32.3 \\
Beneficiaries & 95 & 49.4 \\
Total & $\mathbf{1 9 2}$ & $\mathbf{1 0 0 . 0}$ \\
\hline Source: Primary Data, 2021 & in proving information related to customer care \\
Information presented in Table 4.6 evidenced that & strategies and business volume. \\
49.5\% are beneficiaries or clients at Kenya & 4.2 Finding out the Relationship between \\
Commercial Bank, 32.4\% of respondents are & Customer Care and Business Volume \\
working in the department related to customer care & The third objective found out the correlation between \\
services. In addition, 9.9\% are in sales department & customer care and business volume. In this regards a \\
while 4.2\% are in management position. Finally, & correlation and regression analysis were performed \\
$2.1 \%$ are accountants while the same percentage are & in order to evaluate either a positive or a negative \\
in internal audit department. These show that most of & correlation between customer care and business \\
pertinent department are represented and are crucial & volume.
\end{tabular}

Table 4. 7 Correlation between customer care and business volume

\begin{tabular}{|c|c|c|c|c|}
\hline & & $\begin{array}{l}\text { Number of } \\
\text { Branches }\end{array}$ & Customer Base & Revenues \\
\hline \multirow[t]{3}{*}{$\begin{array}{l}\text { Handling } \\
\text { complaint }\end{array}$} & $\begin{array}{l}\text { mer Pearson } \\
\text { Correlation }\end{array}$ & $.592^{* *}$ & .189 & $.931^{* *}$ \\
\hline & $\operatorname{Sig}(2$-tailed $)$ & .000 & .086 & .000 \\
\hline & $\mathrm{N}$ & 192 & 192 & 192 \\
\hline \multirow[t]{3}{*}{ Customer care policy } & $\begin{array}{l}\text { Pearson } \\
\text { Correlation }\end{array}$ & $.681^{* *}$ & .145 & $.802^{* *}$ \\
\hline & Sig.(2-tailed) & .000 & .191 & .000 \\
\hline & $\mathrm{N}$ & 192 & 192 & 192 \\
\hline \multirow[t]{2}{*}{$\begin{array}{l}\text { Offering loans } \\
\text { competitive rates }\end{array}$} & $\begin{array}{l}\text { at Pearson } \\
\text { Correlation }\end{array}$ & $.370^{* * *}$ & $.304^{* *}$ & $.669^{* *}$ \\
\hline & Sig.(2-tailed) & .001 & .005 & .000 \\
\hline
\end{tabular}




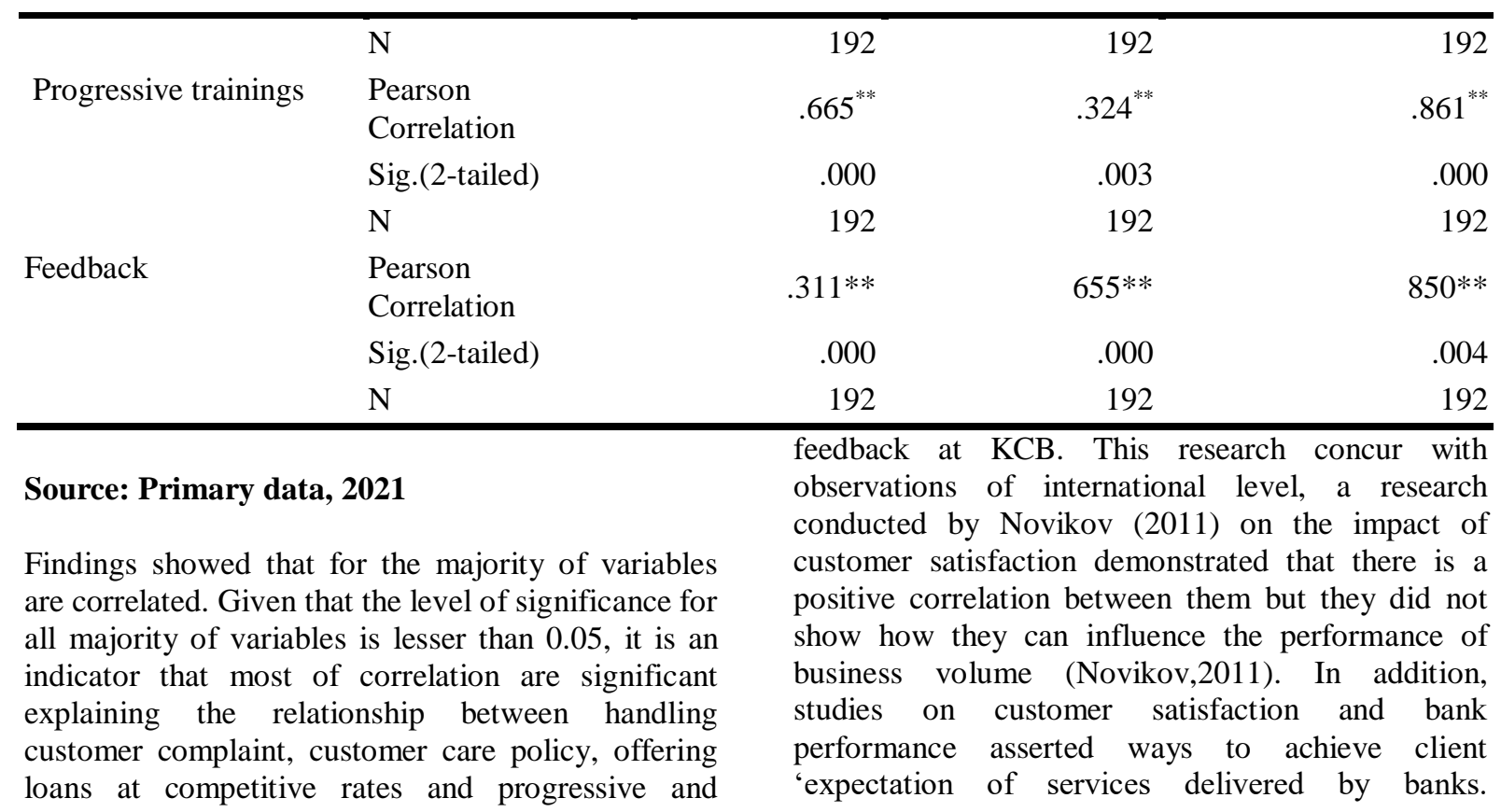

Table 4.8 Model Summary

\begin{tabular}{lllll}
\hline Model R & R & R Square & $\begin{array}{l}\text { Adjusted } \\
\text { Square }\end{array}$ & R std. Error of the Estimates
\end{tabular}

\begin{tabular}{lllll}
\hline 11 & $.710^{\mathrm{a}}$ & .505 & .457 & .17809 \\
\hline
\end{tabular}

Predictors: (Constant), Handling Customer complaint, Customer care policy, offering loans at competitive rates, Progressive trainings and Feedback.

Results presented in Table 4.8 demonstrated a significant effect of independent to dependent variables as indicated by 0.71 . The business volume is subjected to handling customer complaint, customer care policy, offering loans at competitive rates and progressive and feedback. The model reveals a change of $45.7 \%$ on business volume owing to modification in handling customer complaint, customer care policy, offering loans at competitive rates and progressive and feedback.

For this perspective, the attraction of new clients, retention of them and to withstand in competitive environment, bank necessitate to be competent enough to meet customer satisfaction (Oso \&Onen, 2011).

Table 4.9 Analysis of Variance

\begin{tabular}{llllll}
\hline \multicolumn{1}{c}{ Model } & Sum of Squares & $\mathrm{df}$ & Mean Square & $\mathrm{F}$ & Sig. \\
\hline Regression & 1.357 & 5 & .339 & 10.693 & $.000 \mathrm{~b}$ \\
Residual & 1.332 & 187 & .032 & & \\
Total & 2.689 & 192 & & & \\
\hline
\end{tabular}

a. Dependent Variable: Business Volume

b. Predictors (Constant), Handling Customer complaint, Customer care policy, offering loans at competitive rates, Progressive trainings and Feedback.

The analysis of variance shown that $F(5,187)=10.693$ and the value of significance is 0.000 .

The $\mathrm{F}$ test outcome which is giving a measure of the absolute fit of the model the data. The $\mathrm{F}$ results indicated the highly significant $(\mathrm{P}<0.01)$, therefore, the model did fit the data.

The findings shown that there is straight line depicting a linear relationship, indicating the relationship between these two variables (customer care along with the business volume at KCB Rwanda Bank Limited).

Agyapong (2011), when customers are highly satisfied, they may encourage the success or 
performance of banks. According to Company (2011), there was a clean and remarkable correlation between satisfaction and development or success of banks. Therefore, in order to attain the success of banks, there is a need to ameliorate the customer care service delivered. The findings from this study suggested that customer care should be improved since they positively affect banking industry. Therefore, This did not reveal how customer care impacted business development.

Table 4.10 Regression Coefficient Analysis

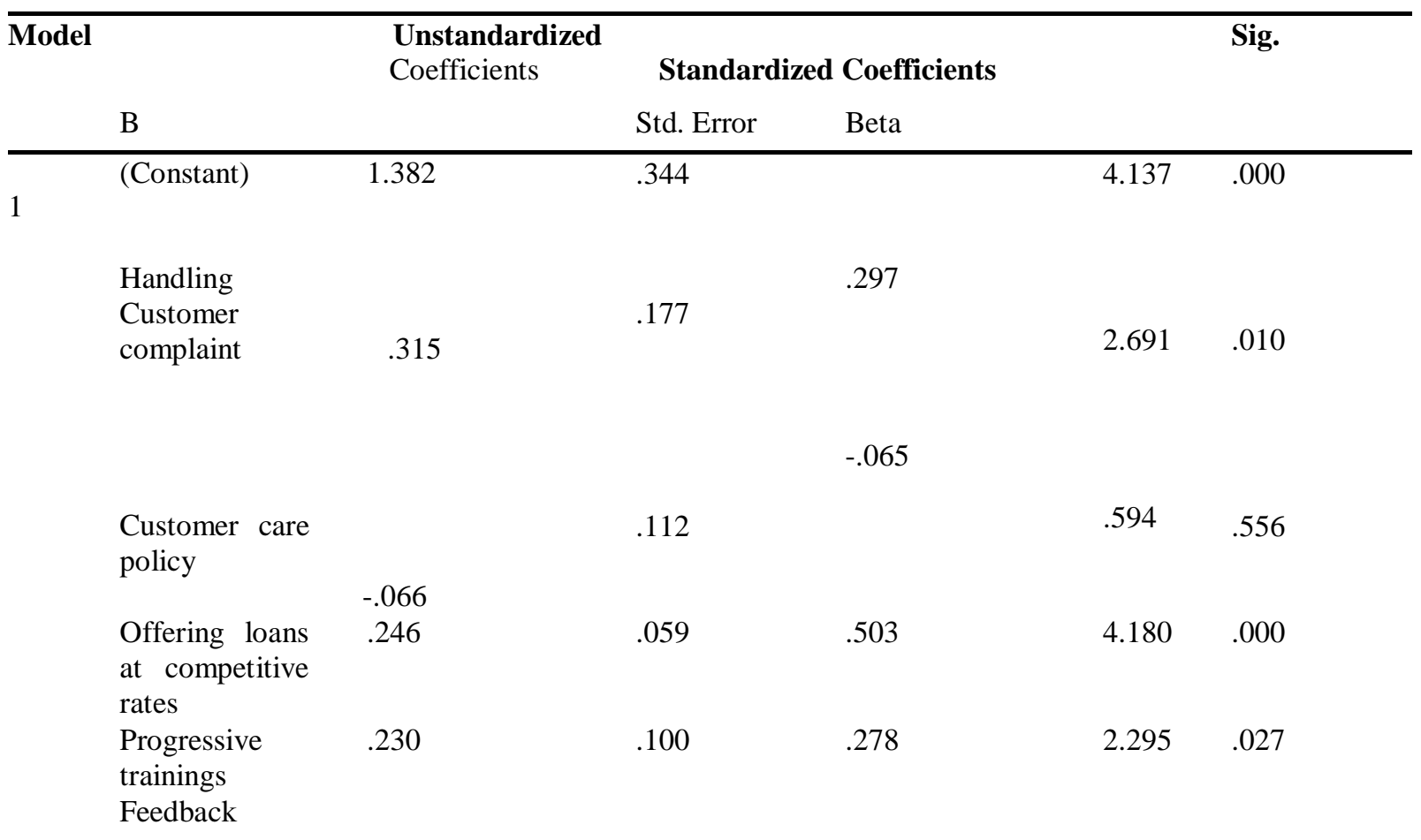

\section{a. Dependent Variable: Business Volume}

In Table 4.10, it was indicated that handling customer complaints is more likely to affect positively business volume with a $\mathrm{p}$ value of 0.010 , $\mathrm{t}=2.69$, the correlation between customer care policy at $\mathrm{KCB}$ and business volume is revealed to be not significant with a $\mathrm{p}$ value of $0.556, \mathrm{t}=0.594$, the correlation with customer care policy was negatively affecting business volume with -0.066 and constant of 1.382. Except customer care policy, all other intendent variables were statistically correlated with business volume increased at KCB since their $\mathrm{p}$ value were less than 0.05 .

This study concur with the levels Natuhwera (2011), on the effects of customer care in influencing performance in Rwandan hotel industry in 2016 evidenced the existence of a strong correlation between customer care and business volume. This is when there is an involvement and commitment of all bank managers and employees, a reliance on organization's responsiveness to the needs of its clients and it must establish and assess future expansion. Moreover, the research has also found out that customer care service influence highly the business volume. The service sector accounts for
$44 \%$ of Rwandan economy depends on customer care quality. In general, the average business in Rwanda loses between $10 \%$ to $30 \%$ of its customers annually

$\mathrm{Y}=1.382+0.315 \mathrm{X}_{1}-0.066 \mathrm{X}_{2}+0.246 \mathrm{X}_{3}+0.230 \mathrm{X}_{4}$

WhereX $_{1}=$ Handling Customer complaint; $\mathbf{X}_{\mathbf{2}}=$ Customer care policy, $\mathbf{X}_{\mathbf{3}}=$ Offering loans at competitive rates, $\mathrm{X}_{4}=$ Progressive trainings and feedback and $\mathrm{e}=$ Scholastic term.

\section{Conclusions}

the study asserts that handling customer complaints is more likely to positively affect business volume with a $\mathrm{p}$ value of $0.010, \mathrm{t}=2.69$, the correlation between customer care policy at KCB Bank and business volume proved not to be significant with a $\mathrm{p}$ value of $0.556, \mathrm{t}=0.594$, the correlation with customer care policy was negatively affecting business volume with -0.066 and constant of 1.382.Banks should design a regular service training program on customer service for the entire personnel to increase their customer relations or service knowledge that affect the business volume in order to maintain customers. The management of the bank should invest more in procurement of efficient 
technology that would decrease the waiting time of customers in their trial to have access on some services as well as increasing the quality of their services in general.

\section{Acknowledgments}

I wish to acknowledge Dr. James Kant Kamuhanda(PhD) and Sammy OnsotiNyaberafor his contribution to this work from the beginning up to its completion. I extend my acknowledgement to the authorities of KCB Ltd for their support and cooperation during this study.

\section{Reference}

[1] Abdulla, J. Baker, S. \& Vlasic, B. (2010). Environmental performance In a Banking Perspective. Journal on Finance and Banking 33(1) 22-33.

[2] Abidoo, K. A. (2011). Predicting Customer Churn in the Mobile Telecommunication Industry, A Case study of MTN Ghana, Kumasi.

[3] Agbor, J. M. (2011). The Relationship between Customer Satisfaction and Service Quality: A study of three service sector in Umea. (J. Eriksson, Ed.) Umea: Umea School of Business.

[4] Agyapong, D., Agyapong, G. K. Q., \&Darfor, N. K. (2011). Criteria for assessing small and medium enterprises' borrowers in Ghana. International Business Research, 4(4), 132-138. http://dx.doi.org/10.5539/ibr.v4n4p132

[5] Alvi, M.H. (2016). A Manual for Selecting Sampling Techniques in Research, University of Karachi, Iqra University.

[6] Amah, E. \&Ahiauzu, A. (2013). Employee involvement and organizational effectiveness, Journal of Management Development, 32 (7). 661-674.

[7] Anandpadmanabha, N. (2011). Value Added Service in India. KunligaTekniskaHogskolan . India: Royal Institute of Technology.

[8] Armstrong (2010), Principles of Marketing, Pearson Prentice Hall.

[9] Baruah M, 2013, Employee Retention: A Review of Literature. IOSR Journal of Business and Management. 14(2). 08-16

[10] Blaxter, L.; Hughes, C.; \& Tight, M. (2010). How to Research, $2^{\text {nd }}$ Ed. (Open University Press, Celtic Court 22 Ballmoor Buckingham MK18 1XW).

\section{ISSN 2455-6378}

[11] Company, P. T. (2011). Customer Care as a critical Factor for increasing the Customer Value and Ensuring Operational Success in the Social Customer Economy. In Customer Care Concept 2.0.

[12] Creswell, J. W. (2013). Qualitative inquiry and research design: Choosing among five approaches. Thousand Oaks, CA: Sage Publications.

[13] Drost, E. A. (2011). Validity and reliability in social science research education. Research and Perspectives, 38, 105-123, Retrieved $25^{\text {th }}$ February, 2020 , from

http://www.erpjournal.net/wpcontent/uploads/2012/07/ERPV38-1.Drost-E.-

[14] D'yakonov, B. P., (2013). Examining Theoretical and Emperical Connections. International Journal of Business and Social Science., Vol.2, No. 20.

[15] Goncharenko, T. V., (2012). The quality of banking services to of individuals as a basis for activation of the savings process.] Naukaiekonomika, 5 (13),

[16] Haenisch, J.P. (2012). Factors Affecting the Productivity of Government Workers, Sage Open, 2 (1), pp. 1-13.

[17] Isaev, R. A., (2011), Methods to ensure and improve the quality of the customer service. Methods of Quality Management] 6, p. 4-12.

[18] Ishchenko, A. A., (2014). Improved approaches to assessing the management of the commercial bank] Azimutnauchnykhissledovaniy: ekonomikaiupravlenie, 1, p. 4750.

[19] Jackson, L. S. (2011). Research Methods and Statistics: A critical thinking approach (4th ed.). Retrieved from http://books.google.com on $17^{\text {th }}$ December, 2019.

[20] Jackson, L. S. (2014). Research Methods: A Modular Approach. (3rd ed.). $\quad$ Retrieved from http://books.google.com on January $21^{\text {st }}, 2020$.

[21] Jackson, L. S. (2016). Research Methods and Statistics: A critical thinking approach (5th ed.). Boston: Cengage Learning. Retrieved from https://books.google.com/ on January $21^{\text {st }}, 2020$.

[22] Jawara, F. \&Kwa, A. (2003) Behind the Scenes at the WTO: The real world of 
international trade negotiations. London: Zed Books, 2003, pp. 197.

[23] Jeston J. \&Nelis J., 2013, Business Process Management (p. 504). Burlington: Routledge.

[24] Jibril, A.K. \&Nwanmou, C.N. (2012).Research Method in Social Sciences and Education.Umuahia: Cijeh Concept Publisher.

[25] Korolev, O. G., 2006, Organization of the administrative account in a commercial bank] (p.160). Moscow: Ekon. Nauki.

[26] Kothari, C.R. (2010). Research methodology methods and techniques ( $2^{\text {nd }}$ ed.). Delhi,India: New Age International publishers.

[27]Lang, R., Harbison Tostanoski, A., Travers, J., \& Todd, J. (2014). The only study investigating the rapid prompting method has serious methodological flaws but data suggest the most likely outcome is prompt dependency. Evidence-Based Communication Assessment and Intervention, 8(1), 40-48.

[28] Mahapatra, G. (2018). Interview with Mr Gaurav Vasu, Founder and CEO, Unearth Insights. South Asian Journal of Human Resources Management, 5(2), 254-260.

[29] Northouse, P.G. (2010). Leadership: Theory and Practice. (3rd Ed). San Francisco, CA. Sage Publications, Inc.

[30] Novatorov, E. V. \&Novitskaya, V. D., (2012).Modification of empirical testing and measurement techniques SERVQUAL for service quality in relation to banking services] Marketing v sferefinansovykhistrakhovykhuslug, 1, p. 22--32.

[31]Novikov, A. S., (2011). Quality Management of customer service in the banking system] Finansy, den'-gi, investitsii, 2, p. 27-28.

[32] Oso, W. Y., \&Onen, D. (2011). A general guide to writing research proposal and report.Nairobi: Prints Arts Limited.

[33] Potluri, R. M., \&Mangnale, V. S. (2011). Critical factors of customer satisfaction in Ethiopian service sector. Asian Journal of Business Management, 3(1), 1-7. Publishing house "“Omega-L"”

[34] Salimova, T. A., (2013) Quality management] (p. 376). Moscow: Service Climate and Customer Satisfaction: Examining Theoretical and Emperical Connections. International Journal of Business and Social Science, Vol.2, No. 20.

[35] Simon Gyasi Nimako, F. K.-B. (2010). Overall Cusiontomer Satisfaction in Ghana's Mobile Telecommunication Network: Implications for Management and Policy. Researcher on business and marketing, Volume 7 (3/4).

[36] Toolkit, E. B. (2013). In How You Can Profit From E- Business. Ontario, Canada: E- Business Toolkit.

[37] Uddin, M. B., \& Akhter, B. (2012). Determinants of Customer Satisfaction of Banking Industry in Bangladesh.Pak. J. Commer. Soc. Sci, 6(2), 242-256

[38] Wandaogou, A. M. M., \&Jalulah, S. P. (2011). Evaluation of customer satisfaction with internet banking service quality in the banking industry in Ghana: A case study of Ghana Commercial Bank Ltd and Merchant Bank of Ghana Ltd CPp. 35-38.

[39] Ngahu, R. (2001). The Distribution and Redistribution of Income: A Mathematical Analysis, $2^{\text {nd }}$ Edition, Manchester University Press.

[40] Balunywa, W. (2015). Business Administration, $3^{\text {rd }}$ Edition. The business Publishing group Kampala.

[41] Tumwebaze J. (2013) Customer care in Business Enterprises. A case study of MTN Uganda

[42] R. Gera (2011) Modelling e-service quality and its consequences in India.

[43] Natuhwera, C. (2011) Customer care and customer satisfaction in hotel. A case study of Sheraton Hotel Kampala (Published B. A. project) Makerere University. 